intermingling between the Melanesian and Polynesian races. On a closer examination I always found that such men were covered from head to foot with an inveterate form of body ringworm-a scaly skin-eruption, which affects in a greater or less degree quite two-fifths of the natives of this part of the group-and that in all their other physical characters they belonged to the Melanesian type. In its most aggravated and chronic condition this parasitical disease implicates the skin to such a degree that the rapid desiccation and desquamation of the epidermal cells lead to a partial decoloration of the deeper parts of the cuticle, as though the rate of the production of pigment was less rapid than the rate of its removal in the desquamative process.

The hair of the head is generally black, frizzly, and bushy; more particularly amongst the younger adults of both sexes this last character prevails. Amongst middleaged men I have som times observed that the hair arranges itself into entangled corkscrew-like spirals,

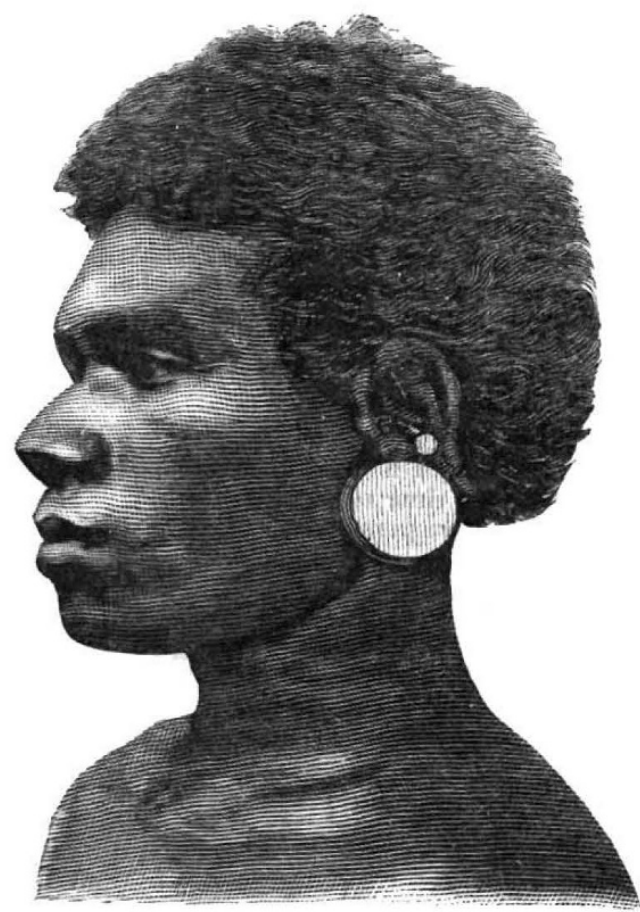

Fig. I.-Native of Santa Anna (an island off the east extremity of St. Christoval). The round disk of w rod in the lobe of the ear should be quite white, the dark sp ts being due to the imperfections of the dry plate. The faint linear

the whole head of hair having much the appearance of a mop placed erect on its handle. Now and then, though rarely, the hair shows a tendency to become straight; I met with one such native near Cape Keibeck, on the north coast of St. Christoval; and I am informed that straight-haired varieties do exist among the hill-tribes in the interior of the island. With regard to the amount of hair on the face, limbs, and body, great diversity is observed amongst natives of the same village. Epilation is commonly employed, but there can be no doubt that the development of hair varies quite independently of such a custom. Out of ten men taken promiscuously from any village, perhaps five would have smooth faces, three would possess a small growth of hair on the chin and upper lip, the ninth would wear a beard, a moustache, and whiskers of moderate growth, whilst the tenth would present a shaggy beard and a hairy visage. The surfaces of the body and limbs are as a rule comparatively free from hair; but hairy men are to be met with in most villages; and on one occasion when in the vicinity of Cape Surville--the eastern extremity of St. ChristovalI visited a village where the proportion of hairy-bodied, hairy-visaged men was in excess of the smooth-skinned element.

From my measurements the form of the skull would appear to be mesocephalic: the cephalic indices ranged between 73 and 82 -the greater number of them being included between 74 and 77 . The facial angle varied in amount between $85^{\circ}$ and $90^{\circ}$. The nose is $\mathrm{g}$ nerally straight, coarse, and somewhat short, the nostrils wide, and the bridge depressed in some instances. Not uncommonly the nose.is arched or aquiline; out of fifty natives amongst whom I took especial notice of this feature, I found that ten possessed an aquiline nose. The countenances of the younger of both sexes are often prepossessing, and amongst the adults I have frequently met with men of some intellectual expression.

Such are some of the leading physical characters of the natives of this part of the Solomon group. To the inhabitants of the small island of Santa Anna, which lies off the east extremity of St. Christoval, the same description will apply; but we find in the still smaller adjacent island of Santa Catalina a subvariety of the Melanesian type characterised by a lighter colour and probably a greater height, although I made no measurements there. The few natives which I saw belonging to the large island of Malayta, which we did not visit, resembled in appearance those of St. Christoval ; and from a few measurements and observations which I made in the Florida subgroup, where the St. Christoval type prevails, it was evident that thus far to the westward the same description of a native of the Solomon Islands was equally applicable. The large neighbouring island of Guadalcanar I had no opportunity of visiting. In the small island of Simbo, further to the west, I found no important difference in the physical characters of the natives except perhaps a rather darker shade of colour. Proceeding westward as far as Treasury Island, our furthest point in that direction, we for the first time came upon a distinct variation in the type of native-a difference which has been a subject for remark even by such usually unobservant people as the masters of trading ships. In their greater height and in the ahnost black colour of the skin, the natives of Treasury Island are at once distinguished from the prevailing native type to the eastward. Their features are more finely cut, and the form of the skull, as shown by the cephalic indices, is more brachycephalic-the range of seven measurements being 78 to 84 , and the mean cephalic index 8I. In some individuals the cheekbones were prominent and the forebeads retreating. As a race the Treasury Islanders are said to evince a fiercer disposition than do the natives in the eastern islands of the Solomon group. The natives of the large adjacent island of Bougainville have the reputation of being amongst the most daring and warlike of the inhabitants of this archipelago ; and probably the examination of their physical characters will exhibit them as a more pronounced type of the Treasury Islanders.

H.M.S. Lark, Auckland, N.Z., February 27

ON A FINE SPECIMEN OF APATITE FROM TYROL, LATELY IN THE POSSESSION OF MR. SAMUEL HENSON

$T \mathrm{HE}$ specimen of apatite represented in the diagram was submitted to my inspection by Mr. Henson last November, and is the most beautiful specimen of this mineral which I have seen. The faces observed were not, however, determined on the specimen itself, but from a plaster cast and a smaller specimen with which $\mathrm{Mr}$. Henson supplied me. From these latter approximate measurements of some of the more prominent angles were obtained by means of a contact-goniometer, which, 
on comparison with the table of angles given in Miller's "Mineralogy," rendered the identification of the more conspicuous planes easy. The remainıng planes were then easily determined from the relation which connects three planes lying in a zone. The forms present are : $o\left\{I_{I}\right\}$, $\left.a\left\{\mathrm{IO}^{\mathrm{I}}\right\}, r_{\{}^{\prime} \mathrm{100}\right\}, r_{1}\left\{22 \overrightarrow{\mathbf{I}}_{j}, x\{2 \mathrm{IO}\}, i\{32 \mathrm{I}\}, u \pi\{4 \overline{\mathrm{I} O}\}, u_{1} \pi\{2 \overline{2} 3\}\right.$.

I had no intention of describing the specimen at the time it was shown me, and did not pay enough attention to the physical characters of the faces to be able to recall them. The specimen was for the most part remarkably limpid, with a pale mauve tint in its purest portions. It was in part penetrated by fine delicate needles of epidote,

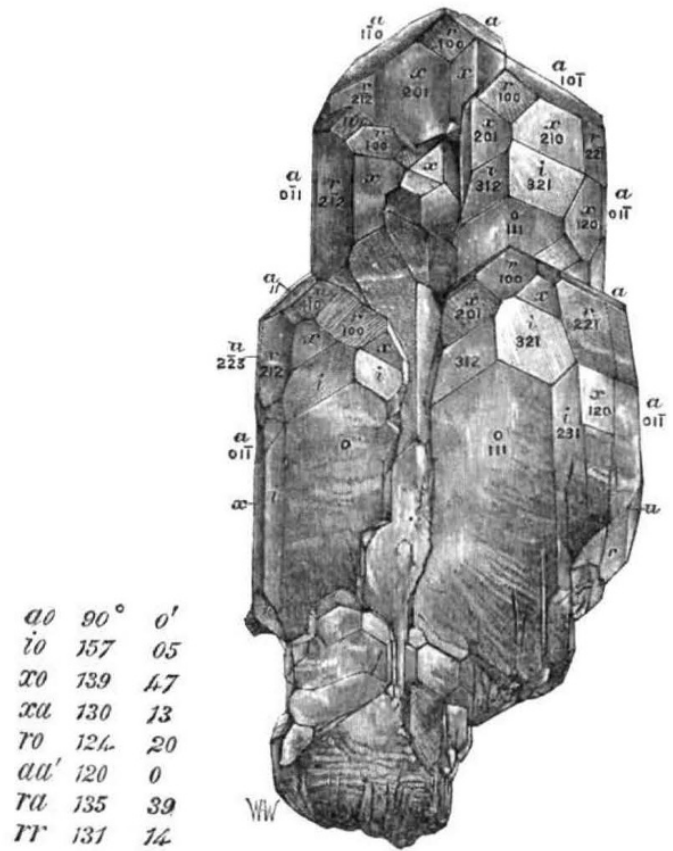

as is shown in the very excellent diagram attached, which gives a very clear and accurate idea of the specimen. A remarkably large crystal from the same locality has recently been added to the mineral collection of the Natural History Museum, Cromwell Road. It is of a much deeper mauve colour than Mr. Henson's specimen; it shows the same general forms, the planes $o$ and $\alpha$ are bright and even, but the small planes, $r, x$, $i$ are somewhat rough. These same characters are also those observed on the faces of such smaller specimens as I bave examined.

W. J. L.

\section{THE EVOLUTION OF THE AMERICAN} TROTTING-HORSE. ${ }^{1}$

THE American trotting-horse is an example of a new 1 breed of animals in process of formation. As yet it can hardly be called a definite breed in which the special and distinctive character is either fully developed in quality or satisfactorily fixed by heredity. Great progress has, however, been made, many individual animals have attained great speed, and all the better ones have derived their trotting excellence in part, at least, through heredity.

The origin of most breeds is involved in considerable obscurity, as to how much they are due to conscious and how much to unconscious selection, what motives led to this selection, how far the enhancement of the special qualities have been due to physical environment, and how far to education, training, nourishment, or cultivation.

${ }^{I}$ By Wm. H. Brewer, from the American Fournal of Science.
The formation of this new breed is so recent, the development of a special quality has been so marked, there is such an abundant literature pertaining to its history, the system of sporting "records" is so carefully planned and comprehensively conducted, and withal has become so extensive, that we have the data for a reasonably accurate determination of the influences at work which led to this new breed being made, the materials of which it is mate, and the rate of progress of the special evolution.

It is as an implement of gambling and sport that the trotter has his chief value to the biological student. Sporting events are published or recorded as the mere everyday use of animals is not, and the records of races give numerical data by which to measure the rate of progress. Similar data do not exist for the study of the evolution of any other breed.

Incidental to the preparation of a paper pertaining to this matter for farmers and breeders, I have compiled and collated certain data which have a scientific as well as economic value, the more interesting portion of which I condense for this paper.

The horse has several gaits which he uses naturally, that is, instinctively. And besides those which are natural, he has been taught several artificial ones, some of which have been much used, particularly in the middle ages. But to trot fast was not natural to horses; when urged to speed they never assumed it, and until within a century the gait was neither cultivated nor wanted by any class of horsemen. A breed of fast trotters, had it been miraculously created, would doubtless soon have perished in that it would have had no use, satisfied no fancy, and found no place in either the social or industrial world as it then was.

Before the present century the chief and almost sole uses of the horse were as an implement of war, an instrument of sport and ceremony, an index of rank and wealth, and an article of luxury.

For all these uses, as then pursued, a fast trotter was not suited, nor was he better adapted to the heavy coaches over rough roads, or the slow waggon-trains of armies. The horse best adapted to all these, however much he may have varied as to size, strength, and fleetness, was one whose fast gait was the gallop or run rather than the trot. For leisurely horseback travelling the ambling gait (or pacing gait as it came to be called in America) was preferred. With increasing use of horses for draft, certain heavy but slow breeds were developed in the Old World, of which the Dutch, Clydesdale, and Norman breeds are examples.

The causes which led to the cultivation of the trotting gait in this country, and the evolution of a breed with which it should be instinctively the fast gait, were various, and the separate value of each as a factor in the problem would be very differently estimated by different persons studying the subject from different points of view. Now that he is so valuable and plays such a part as a horse of use, it is easy to see why a breed of trotting roadsters should be produced to meet certain important demands of our modern civilisation. But this does not explain how the process actually began.

Reasoning a priori, the trotter, as a horse of use, should have originated in western Europe; as a matter of fact, he not only did not begin there, but he was unpopular there until well developed here. Locomotives began to draw armies to the battle-field, the war-horse declined in actual as well as relative importance, the modern, light, steel-spring, one-horse, convenient business waggon as well as the modern buggy came into common use after trotting as a sport was established, and after the gait had been extensively cultivated and bred to. The trottinghorse is specially adapted to various modern uses, but these uses followed his development, rather than led it, although in later days this factor has been an important one in the rate of progress. 